\title{
Respiratory Viral Infections in Transplant Recipients
}

\author{
Catherine Liu, Dora Y. Ho, and Michael Boeckh
}

\section{Introduction}

Respiratory viral infections (RVIs) are common causes of illness in humans. While such infections tend to be mild and self-limiting in healthy individuals, severe or even lifethreatening disease can be seen in immunocompromised hosts, as well as the very young and the elderly. In particular, RVIs are frequently associated with significant morbidity following hematopoietic stem cell transplantation (HSCT) or solid organ transplantation (SOT). A number of RNA and DNA viruses can cause respiratory tract infections. This chapter focuses on the epidemiology, clinical manifestations, diagnosis, treatment and prevention of respiratory syncytial virus (RSV), parainfluenza viruses (PIVs), human metapneumovirus (HMPV), influenza viruses, human coronaviruses (HCoV), and human rhinoviruses (HRV).

The respiratory viruses are associated with a wide range of clinical syndromes in the general population, including the common cold, pharyngitis, tracheobronchitis, laryngotracheobronchitis (croup), bronchiolitis, and pneumonia. For transplant recipients, disease spectrum similarly spans from asymptomatic or mild infections to life-threatening lower respiratory tract involvement, although severe complications tend to be more frequent. The severity and outcome of infection largely depend on the type of virus as well as host factors, including the type of transplantation and the degree of immunosuppression at the time of infection. Coinfections with other pulmonary pathogens including bacteria or fungi,

C. Liu $(\bowtie) \cdot$ M. Boeckh

Fred Hutchinson Cancer Research Center, University of Washington Medical Center, Seattle, Washington, USA e-mail: catherine.liu@fredhutch.org; mboeckh@fredhutch.org

D. Y. Ho

Division of Infectious Diseases and Geographic Medicine, Stanford University School of Medicine, Stanford, CA, USA

e-mail: doraywho@stanford.edu e.g., Aspergillus species, Pneumocystis jiroveci, or other viruses like CMV or more than one respiratory viruses, are also common and can further complicate treatment and lead to poorer outcomes [1-3]. For HSCT recipients, most RVIs occur in $1-10 \%$ of the patients during the first 100 days posttransplantation $[1,4,5]$, with cumulative incidence varying from a few percent (e.g., HMPV, influenza, RSV, PIVs) to 11-22\% such as HCoV and HRV [5]. Infections with RSV, influenza, HMPV, PIVs, and adenovirus have a higher risk of progression from upper respiratory tract infection (URTI) to lower respiratory tract infection (LRTI) and tend to cause the most serious disease, with mortality rate of up to 40-60\% among those with LRTI [6-9]; HRV and $\mathrm{HCoV}$ infections tend to be mild, but severe LRTI from these viruses can rarely occur [10]. Risk factors for disease progression to LRTI include pre-engraftment status, allogeneic transplant, myeloablative conditioning, graft-versus host disease, and lymphopenia [1, 2, 6, 11-15].

SOT recipients can also suffer from severe disease and complications from RVI. Risk factors for disease progression are not as well defined, but those with lung and heart-lung transplant are particularly vulnerable. Cumulative rates of RVIs in lung transplant recipients range from $8 \%$ to $21 \%$ in retrospective studies of 5-7 years [16, 17], and a high incidence of progression to LRTI up to $26 \%$ has been reported [18]. In contrast, the incidence of RVIs among heart, liver, and kidney transplant recipients is similar to that of the general population, although complications are more frequent [19].

In addition to direct effects from viral infection, RVIs may promote immunologically mediated lung injury in HSCT or lung transplant recipients, potentially leading to acute allograft rejection in the case of lung transplant recipients and/or the development of bronchiolitis obliterans syndrome (BOS), which is characterized by progressive circumferential fibrosis of the small terminal airways histopathologically, resulting in fixed airflow obstruction [20,21]. BOS is the major limiting factor for long-term survival after lung transplantation [22-28]. The reported incidence of BOS associated with RVIs ranges from $6 \%$ to $42 \%$ [17, 23], while 
the incidence of acute rejection associated with RVIs varies from $16 \%$ to as high as $82 \%$ [25, 28-30]. For HSCT, BOS is often observed in the setting of chronic graft-versus-host disease, but it has also been associated with RVIs [31-34]. Among the respiratory viruses, RSV, PIV, HMPV, and influenza have all been associated with BOS [30, 35, 36], and mortality associated with these viruses can be up to $20 \%$ in lung transplant patients [37]. For heart, liver, or kidney transplantation, no relationship between RVI and rejection has been noted [19].

\section{Paramyxoviruses}

RSV, PIVs, and HMPV are members of the Paramyxoviridae family. The epidemiology, clinical manifestations, and treatment of each of these viruses are discussed separately.

\section{Respiratory Syncytial Virus (RSV)}

\section{Epidemiology and Clinical Manifestations}

RSV has two subtypes, A and B, with the former typically causing more severe disease. While both subtypes can simultaneously circulate during outbreaks, a few distinct genotypes of each subtype can predominate within a community. The dominant strains can also shift yearly. This shifting of viral strains, along with the waning protective immunity from natural infection, might account for frequent re-infections throughout life [38].

RSV usually causes mild and self-limited URTI in healthy older children and nonelderly adults, but certain patient populations are at risk for developing severe RSV infection, including premature or very young infants, elderly patients with comorbidities, or immunocompromised hosts [39-41]. RSV has been associated with apnea in young or preterm infants [42] and can cause severe LRTI in children including bronchiolitis, pneumonia, and acute respiratory failure [42]. Among adults infected with RSV, more than $80 \%$ are symptomatic, and lower respiratory tract signs and symptoms can occur in a quarter of the patients [43]. Signs of URTI include cough, rhinorrhea, and conjunctivitis, and compared to influenza, RSV is more frequently associated with nasal congestion, ear and sinus involvement, productive cough, and longer duration of illness [43].

\section{RSV Infection in Transplantation}

For transplant patients, RSV is a leading cause of viral respiratory tract infections $[44,45]$. Among HSCT recipients, the incidence may be as high as $10 \%$ during winter months [6]. URTI precedes pneumonia in $80-90 \%$ of patients, and approximately $30-40 \%$ of patients with URTI progress to pneumonia after a median of 7 days [46]. Attributable mor- tality among HSCT patients ranges from $7 \%$ to $83 \%$ [47, 48 , with more recent studies showing mortality rates of about 20-35\% [49-54]. Risk factors for the development of LRTI include allogeneic transplant, mismatched or unrelated transplant, presence of graft versus host disease, myeloablative regimens, advanced age, prolonged lymphopenia, relapse of malignancy, and lack of engraftment $[1,6,8,9$, $12,13,15,55,56]$.

For SOT recipients, RSV-associated mortality rate is significantly lower than that experienced in HSCT [57] although mortality rates among lung transplant patients of up to $20 \%$ have been reported [17, 37]. While there have been some reports of favorable outcomes in lung transplant recipients even in the absence of specific antiviral treatment [58], other studies suggest that up to $33 \%$ of RSV-infected patients develop long-term pulmonary dysfunction [23, 24, 37 and up to $60 \%$ have worsening of BOS stage [58].

\section{Treatment of RSV}

\section{Available Agents for RSV Treatment}

Treatment modalities for RSV are limited to ribavirin with or without the addition of immunomodulatory agents and/ or corticosteroids. Currently, the only Food and Drug Administration (FDA)-approved therapy for RSV is aerosolized ribavirin (1- $\beta$-D-ribofuranosyl-1,2,4-triazole-3carboximide), which was licensed in 1986 for the treatment of RSV LRTI in hospitalized high-risk infants and young children [59]. Ribavirin is a synthetic nucleoside analog with a broad spectrum of activities against many RNA and DNA viruses in vitro and in vivo. It competitively inhibits inosine monophosphate dehydrogenase and can be incorporated into the viral genome, leading to lethal mutagenesis [60]. The drug also has immunomodulatory properties that might contribute to its efficacy in vivo $[61,62]$.

The standard regimen of aerosolized ribavirin consists of a daily dose of $6 \mathrm{~g}$ delivered at a concentration of $20 \mathrm{mg} / \mathrm{ml}$ of sterile water for $18 \mathrm{~h} /$ day. Due to potential teratogenicity, the drug is usually administered to patients within a scavenging tent and preferably in a negative pressure room to prevent environmental contamination. After administration, the room needs to be cleaned to minimize secondary exposure to health care workers and visitors [48]. Women of childbearing potential should not care for or visit patients receiving aerosolized ribavirin. For ease of administration and improved compliance, the drug is often delivered with an intermittent dosing schedule at $2 \mathrm{~g}$ administered for 2-3 h every $8 \mathrm{~h}$ [63, 64]. In a randomized trial of 50 subjects, patients receiving intermittent vs continuous dosing had a lower incidence of progression from URTI to LRTI [65]. The reported duration of treatment is variable in the literature; the 4th European Conference on Infections in Leukaemia (ECIL-4) guidelines recommend a duration of 7-10 days [66]. 
Side effects of aerosolized ribavirin treatment include cough, dyspnea, bronchospasm, rash, nausea, headache, and conjunctival irritation. Patients can also experience claustrophobia and deterioration of pulmonary function. Ribavirin can also be administered intravenously or orally, with major side effects including hemolytic anemia, leukopenia, and hyperbilirubinemia [47].

Intravenous RSV-specific immunoglobulin (RSV-IVIG and palivizumab [PVZ]) were licensed initially for prevention of serious complications from RSV infection in highrisk children (refer to section "Immunoprophylaxis") [67], but they have also been employed for RSV treatment [6872]. Intravenous immunoglobulin (IVIG) is also frequently used for the treatment of RSV and other severe viral infections in transplant recipients. The efficacy of these agents for prophylaxis or treatment among transplant patients has not been evaluated in randomized controlled trials although in an observational study of HSCT patients with RSV LRTI, multivariate analysis did not find any effect of antibody-based therapies on treatment outcomes [73].

\section{Treatment of RSV in HSCT}

The evaluation of any treatment modalities for RSV, or any other respiratory viruses, has been limited by the fact that most published studies are small observational studies which lack standardized definitions of URTI and LRTI, use different dosages and duration of therapy, and are subject to selection and publication bias. Among dozens of reports on the treatment of RSV in HSCT patients, there have only been two small randomized clinical trials. One study of aerosolized ribavirin was discontinued due to slow accrual, after enrollment of 14 patients in 5 years [69]. The other trial enrolled 50 patients and found that an intermittent dosing schedule of aerosolized ribavirin for treatment of RSV URTI was more effective than a continuous dosing schedule for prevention of progression to LRTI [64].

Two pooled analyses of published studies between 1980 and 2010 suggest that treatment of RSV URTI and LRTI with aerosolized ribavirin and IVIG reduces the risk of progression to LRTI in individuals with URTI and reduces mortality $[47,48]$. When compared to no treatment, aerosolized ribavirin decreased the rate of progression to LRTI and mortality with the greatest impact observed when aerosolized ribavirin was given in combination with an immunomodulator. Specifically, when comparing aerosolized ribavirin treatment alone with no treatment, progression to LRTI was decreased from $47 \%$ to $25 \%$ and the mortality rate was reduced from $89 \%$ to $50 \%$ [47]. The addition of immunomodulators such as PVZ, IVIG, and/or RSV-IVIG to ribavirin compared to no treatment decreased progression to LTRI from $45 \%$ to $12 \%$ and mortality rate from $77 \%$ to $24 \%$. There are paucity of reports on the use of intravenous or oral ribavirin, but the combined data suggest a benefit compared to no treat- ment. It is important to recognize that neither of these systematic reviews represented formal meta-analyses; there was no adjustment for confounders, and thus, results should be interpreted with caution. The only trial to date that evaluated PVZ as monotherapy for the treatment of RSV infection in HSCT recipients showed no benefit in prevention of progression to LRTI or mortality [74].

Overall, these analyses show a trend toward improved outcomes with regard to progression to LRTI and mortality among HSCT recipients treated with a combination of aerosolized ribavirin and immunomodulators than those treated with aerosolized ribavirin alone or with intravenous/oral ribavirin, or those given no treatment. However, the use of aerosolized ribavirin is cumbersome and very costly with the price increase in 2015 to $\$ 30,000$ per day [75]. In addition, the aerosolized form of ribavirin is not available in all countries, and the intravenous form is not commercially available in the United States. The experience with oral ribavirin in HSCT is limited and warrants further evaluation, but some studies suggest that it may be a safe and effective alternative to aerosolized ribavirin for the treatment of RSV [51, 76-78]. In a retrospective study of 124 HSCT recipients with $\mathrm{RSV}$ infection, there was no difference in rates of progression to LRTI and mortality among patients receiving oral compared to aerosolized ribavirin [51]. The optimal dose of oral ribavirin for treatment of RSV is unclear and quite variable in the literature [79]. Commonly described dosing strategies include a fixed dose of 600-800 mg two or three times a day or a loading dose of $10 \mathrm{mg} / \mathrm{kg}$ followed by $20 \mathrm{mg} / \mathrm{kg} /$ day divided into three doses, adjusted for renal failure [51, 77, 79].

\section{Treatment of RSV in SOT}

Similar to the HSCT population, the mainstay of treatment for paramyxoviral infections in SOT populations has been aerosolized ribavirin [37, 80]. In an observational study, a combination of aerosolized ribavirin, IVIG, and corticosteroids was found to be safe and effective in preserving lung function in lung transplant recipients after RSV or PIV infections 29. Few studies have examined the role of oral ribavirin. Pelaez et al. [81] reported treatment of five lung transplant patients with RSV infection using oral ribavirin in combination with methylprednisolone and found this regimen well tolerated and effective with mean forced expiratory volume in $1 \mathrm{~s}$ (FEV1) returning to baseline with treatment. In a prospective observational study, oral ribavirin treatment in 38 patients with RSV, PIV, or HMPV infection was associated with earlier recovery of graft function and prevention of BOS as compared to 29 patients with only supportive care including corticosteroids [82]. In one study that evaluated lung transplant patients who received either aerosolized or oral ribavirin for RSV infection, no significant differences in 6-month outcomes were noted between the two groups, 
but variations in their adjunctive therapies, e.g., use of corticosteroids, IVIG, and/or montelukast, might have altered the patients' clinical response [83]. Intravenous ribavirin was also found to be a safe and cost-effective treatment among 18 patients with RSV after lung transplantation [84].

Overall, these studies support the use of ribavirin in treating RSV infection among SOT recipients although it is important to recognize that the evidence is limited to small, uncontrolled studies. There are significant variabilities among these studies regarding the dose and duration of treatment as well as the use of immunomodulating agents such as corticosteroids, IVIG, or PVZ as adjunctive measures.

More recently, a new agent presatovir (GS-5806), an orally bioavailable antiviral agent that inhibits fusion of RSV with host cell membranes, is being developed for treatment of RSV infection. Phase II clinical trials studying HSCT and lung transplant recipients were completed, and the data on lung transplant recipients has been published [85]. In this Phase $2 b$ randomized controlled trial that enrolled a total of 61 lung transplant patients with RSV, presatovir was apparently well tolerated, but its use did not result in improved viral or clinical or outcomes.

\section{Parainfluenza Viruses (PIVs)}

\section{Epidemiology and Clinical Manifestations}

There are four distinct serotypes of PIVs, namely, PIV-1 to -4 . These viruses can circulate throughout the year in most communities, although PIV-3, the dominant serotype affecting transplant populations, seems to have the highest prevalence during spring and summer seasons [38]. PIVs cause a spectrum of respiratory tract infections similar to RSV, but most are URTIs and result in fewer hospitalizations. PIV-1 and, to a lesser extent, PIV-2 are the principal causative agents of croup or laryngotracheobronchitis, primarily in children between the ages of 6 and 48 months. PIV-3 is most frequently associated with pneumonia and bronchiolitis; neonates, immunocompromised, and the elderly are at particular risk for severe disease. PIV-4 is infrequently detected and is thought to cause mostly asymptomatic or mild infections.

\section{PIV Infection in Transplantation}

Symptomatic PIV infection affects about $3-7 \%$ of HSCT recipients $[2,64,86,87]$ and approximately $3-5 \%$ of lung transplant recipients $[28,88]$. LRTI can develop in up to $50 \%$ of PIV-infected HSCT patients, with associated mortality rate ranging from $12 \%$ to $57 \%$ [2, 8, 64, 86, 87, 89, 90]. Two large retrospective studies have evaluated PIV infections in HSCT and found that most patients (70-87\%) presented with URTI, but $13-24 \%$ subsequently progressed to LRTI $[2,64]$. Among those with LRTI, overall mortality at 30 days was $17-35 \%[2,64]$. Independent risk factors for progression to LRTI included receipt of corticosteroids at the time of URTI diagnosis, neutropenia, an APACHE II score $>15$, and respiratory coinfections. Independent predictors of death included relapsed or refractory underlying cancer, APACHE II score $>15$, and high-dose corticosteroid use considered in patients given cumulative dose of prednisolone $>600 \mathrm{mg}$ within 4 weeks of PIV diagnosis [2, 14]. Whether steroids are still important if adjusted for lymphopenia requires further study. While RSV infections are always symptomatic, asymptomatic shedding is present in about $1 / 3$ of PIVinfected HSCT patients [91]. In a surveillance study of lung transplant recipients, asymptomatic PIV infection was present in $70 \%$ of patients [28].

PIV LRTI has also been associated with a significantly increased risk of severe airflow decline after HSCT when compared to RSV 31. For lung transplant patients, PIV has been associated with acute rejection and BOS $[18,28,88$, $92,93]$.

\section{Treatment of PIV}

A number of studies reported treatment of PIV with ribavirin (see section "Treatment of RSV"), but most are limited to case reports or small series. For HSCT, both aerosolized $[2,86,87,94,95]$ and oral ribavirin [96, 97] have been employed, although some patients received intravenous ribavirin when they did not respond to aerosolized or oral treatment $[86,98]$. In a series that included 55 patients with PIV-3 LRTI, 31 were treated with aerosolized ribavirin with or without IVIG in a nonrandomized fashion. Such therapy did not appear to alter mortality from PIV-3 pneumonia or decrease the duration of viral shedding [2]. A more recent retrospective study evaluated 173 HSCT recipients with PIV infection [90]. Forty-one patients with LRTI were treated with aerosolized ribavirin with or without IVIG, but 100-day mortality of this group was similar to those with LRTI not treated with ribavirin. Overall, there is no convincing evidence that ribavirin is effective for treatment of PIV upper or lower tract disease in HCT recipients. Effective prophylaxis and treatment for PIV in HSCT population are desperately needed.

Successful treatment of PIV LRTI has been reported in heart transplant recipients with aerosolized ribavirin or with intravenous ribavirin plus methylprednisolone $[99,100]$ as well as in a kidney transplant recipients with aerosolized ribavirin and IVIG [101] although none of these studies included controls.

DAS181 is a novel sialidase fusion protein with activities against multiple strains of influenza and PIVs. It has been used for PIV treatment in a small number of HSCT and lung transplant recipients. The drug was found effective in most of these cases and was well tolerated [102-106]. A phase II, randomized, double-blind, placebo-controlled study to 
examine the effects of DAS181 in immunocompromised hosts with LRTI by PIV has been completed, but no results have been published to date.

\section{Human Metapneumovirus (HMPV)}

\section{Epidemiology and Clinical Manifestations}

HMPV was first described in 2001 among Dutch children with bronchitis [107], although serological studies indicate that it has been a cause of human infection since 1958 [108]. There are two subgroups of HMPV, A and B, and each with two clades, A1, A2, B1, and B2. All four subtypes cocirculate, while a single subtype tends to dominate each year [109]. HMPV has a worldwide distribution; it circulates in late winter to early spring in temperate climates and in late spring to summer in tropical regions [108].

HMPV may contribute to $12-20 \%$ of all previously virus-negative LRTI [110]. When compared to RSV, infection with HMPV tends to occur in slightly older children and cause milder symptoms, but severe disease can occur among small children, elderly, and those with immunosuppression or chronic medical conditions [111]. Clinical manifestations range from mild URTIs to severe pneumonia. Elderly patients are much more likely to experience dyspnea and wheezing than young adults, and hoarseness is a more common complaint when compared to other paramyxoviruses [112]. Among hospitalized patients and recipients of HSCT, wheezing is prominent and noted in up to 80-90\% of patients [113, 114].

\section{HMPV Infection in Transplantation}

For patients with hematologic malignancies or HSCT, HMPV is responsible for approximately 3-14\% of RVIs [114-117]. A systematic review of HMPV infections among HSCT recipients and hematologic malignancy patients found that despite lack of directed antiviral therapy, overall mortality rates are low $(6 \%)$ unless patients progress to LRTI (27\%) [118]. Approximately one-third of patients with HMPV URTI develop LRTI [119].

In lung transplant recipients, HMPV is responsible for 14-30\% of RVIs with a similar morbidity when compared to other community-acquired respiratory viruses [3, 35, 36, 120]. Acute HPMV infection has been associated with allograft rejection [36]. In a study [120] of 89 lung transplant patients who presented with RVIs, HMPV and RSV were equally prevalent and had similar clinical manifestations, although severe bronchospasm was less common with HMPV. A significant number of patients with either HMPV or RSV infection developed graft dysfunction $(63 \%$ and $72 \%$, respectively), but onset or progression of BOS occurred only in patients with RSV (38\%) at 6 months and in none with HMPV. Another study of 60 lung transplant patients also showed that HMPV infection increased the risk of acute graft rejection without associated chronic rejection or BOS [3, 120].

\section{Treatment of HMPV}

Treatment for HMPV is largely supportive, as there is currently no antiviral therapy licensed for this virus. Ribavirin is active against HMPV in vitro and in animal models [121, 122]. In clinical settings, there have been scattered reports in the literature describing HMPV cases treated successfully using aerosolized, oral, or intravenous ribavirin given with or without IVIG [3, 120, 123-126]. However, these studies did not include any untreated control groups, and the efficacy of these regimens cannot be determined. Some have suggested that ribavirin with IVIG may be considered as a treatment option for patients with severe disease [125], but this approach is not routinely used.

Several new approaches for treatment of HMPV are in development, including monoclonal antibodies against the fusion protein $[127,128]$ or synthetic peptides with antiviral activities [129]. Their efficacies against HMPV have been demonstrated in vitro and in animal models, but studies in human have not been reported.

\section{Diagnosis of Paramyxoviruses}

\section{Radiographic Evaluation}

LRTI by respiratory viruses produces a spectrum of imaging findings; with the most common high-resolution chest computed tomography (HRCT) scan, observations include small, poorly defined centrilobular nodules or tree-in-bud opacities, ground-glass opacities, bronchial wall thickening, and airspace consolidations, which may be difficult to differentiate from other causes of pulmonary consolidation [130-137]. There is considerable overlap in the imaging appearance of viral, bacterial, mycobacterial, and fungal respiratory tract infections in transplant population. The findings such as treein-bud opacities, bronchial wall thickening, and peribronchiolar consolidation may suggest a viral etiology [138]. HRCT findings between immunocompetent and immunocompromised patients are relatively similar [139], but infection with co-pathogens is common among transplant recipients, thus complicating interpretation of radiographic findings. Correlation with patient immune status, recent treatment, and exposure history, as well as epidemiologic factors, are essential to help narrow the list of possible etiologies both infectious and noninfectious and to guide diagnostic testing and appropriate therapy [130].

\section{Laboratory Diagnosis of Paramyxoviruses}

Laboratory diagnosis of respiratory viruses is usually made by analysis of respiratory secretions. Samples can 
be obtained as a nasal wash, nasopharyngeal or throat swab, bronchoalveolar lavage, or, for those incubated, tracheal aspirate. Detection of the virus in the respiratory samples can be performed by cell culture, antigen testing, and PCR.

Viral isolation by cell culture used to be the gold standard for diagnosis but has largely been replaced by molecular studies. Reverse transcriptase (RT)-PCR is now routinely used for respiratory viral diagnosis for the detection of RNA viruses in respiratory secretions [140] and has higher sensitivity than either viral culture or antigen detection assays, particularly in immunocompromised patients [91, 140]. Compared with culture, the sensitivity and specificity of RT-PCR techniques can reach 100\% and 95-98\%, respectively [141-143]. PCR-based tests for respiratory viral detection are often designed as part of a multiplex PCR assay that can allow detection of multiple respiratory pathogens simultaneously [144], and rapid point-of-care tests are being developed as well $[145,146]$.

\section{Transmission and Prevention of Paramyxovirus Infection}

The modes of transmission of PIVs and HMPV are not as well studied as RSV, but these respiratory viruses are mostly transmitted by direct person-to-person contact, through exposure to nasopharyngeal secretions from infected individuals such as respiratory droplets or by self-inoculation after touching contaminated surfaces has also been described [147, 148]. Outbreaks of RSV, PIVs, or HMPV have been reported in outpatient clinics, in long-term care facilities, and in hospitals, including hematology and HSCT units [94, 149-153]. To prevent transmission of respiratory viruses in health care setting, policies and procedures regarding patients with respiratory viruses should be formulated; in particular, compliance with proper hand hygiene and contact precautions are of paramount importance. Other infection control measures include isolating infected patients in private room, cohorting patients, and/or limiting transport of patients from their rooms. During a nosocomial outbreak, personnel caring for infected patients should be restricted from caring for uninfected high-risk patients if possible [154-156].

\section{Immunoprophylaxis}

PVZ is a RSV-specific humanized monoclonal antibody directed against the F glycoprotein of RSV and is FDA approved for immunoprophylaxis against RSV in high-risk children. Data for its use in immunocompromised adult patients are limited [48, 68], with only one uncontrolled study in the literature reporting the use of PVZ as immu- noprophylaxis during an RSV outbreak in an adult HSCT unit [150]. RSV-IVIG prophylaxis has also been studied in high-risk adult HSCT recipients; an increase in antibody titers against RSV was demonstrated, but the study was underpowered to evaluate its efficacy [157]. There are several monoclonal antibodies against RSV under development.

\section{Vaccines}

Despite the major clinical importance of paramyxoviruses, there is currently no vaccine approved for these viruses in humans. Using various strategies for vaccine development, those tested in animal models include live-attenuated virus vaccines including chimeric and recombinant variety, inactivated virus vaccines, and subunit vaccines. A number of them are currently in phase I-II clinical trials [158-161].

\section{Other Strategies}

In a retrospective study of 37 HSCT patients with pretransplant RSV URTI, 34 patients had their transplant delayed or conditioning aborted [162]. Overall, RSV pneumonia occurred in 1 of 34 patients for whom HSCT was delayed, compared with two of three patients for whom there was no delay. This study suggested that for HSCT candidates with pretransplant RSV URTI, a delay of HSCT might reduce the risk of developing RSV pneumonia. Thus, the strategy of delaying transplantation to prevent progression of a viral URTI to LRTI is recommended unless precluded by progression of underlying malignancy. There are limited data for other respiratory viruses $[66,147]$ although some proposed guidance is available (Table 40.1) [163].

\section{Orthomyxovirus: Influenza}

Influenza belongs to the family Orthomyxoviridae with three types, influenza A, influenza, $B$, and influenza $C$ virus. Influenza $\mathrm{A}$ viruses are further classified into subtypes based on their hemagglutinins (HA) and neuraminidases (NA). One of the unique features of influenza virus is the frequency by which antigenic variation occurs which is the reason that influenza continues to be a cause of major epidemics. Annual variation of the influenza virus is due to relatively minor antigenic changes within the HA and/or NA and is known as antigenic drift. Major changes in HA or NA through genetic reassortment or a major mutation are known as antigenic shift and occur once every 10-30 years. This results in an entirely novel strain to which the population has no immunity, leading to an unhindered global spread; the last pandemic occurred in 2009 with the emergence of a novel strain of influenza A/H1N1. 
Table 40.1 Recommendations for respiratory viral infections prior to hematopoietic stem cell transplantation

\begin{tabular}{|c|c|c|}
\hline Virus & Recommendation for URTI & Recommendation for LRTI \\
\hline RSV & $\begin{array}{l}\text { Delay transplant if possible } \\
\text { If not possible to delay, consider oral ribavirin }\end{array}$ & $\begin{array}{l}\text { Delay transplant; consider ribavirin if delay is not feasible } \\
\text { (anecdotal data) }\end{array}$ \\
\hline Influenza virus & $\begin{array}{l}\text { Delay transplant if possible and treat } \\
\text { If not possible to delay, treat }\end{array}$ & Delay transplant and treat \\
\hline Parainfluenza virus & $\begin{array}{l}\text { Delay transplant if possible } \\
\text { If not possible to delay, supportive care }\end{array}$ & $\begin{array}{l}\text { Delay transplant; consider ribavirin if delay is not feasible } \\
\text { (anecdotal data) }\end{array}$ \\
\hline Metapneumovirus & Delay transplant if possible & Delay transplant; no data on ribavirin \\
\hline Rhinovirus & No delay needed for URTI & Delay transplant for allogeneic transplant if feasible \\
\hline Coronavirus & No data & No data \\
\hline Bocavirus & No data & No data \\
\hline
\end{tabular}

Adapted from Waghmare et al. [163]

Table 40.2 Role of corticosteroid treatment in progression of respiratory viral illnesses

\begin{tabular}{|c|c|c|c|c|c|c|c|c|}
\hline \multirow[b]{2}{*}{ Virus } & \multicolumn{4}{|l|}{ Progression } & \multicolumn{4}{|l|}{ Mortality } \\
\hline & Steroid dose per day & & HR $(95 \%$ CI $)$ & $\mathrm{P}$-value & Steroid dose per day & & HR $(95 \% \mathrm{CI})$ & $\mathrm{P}$-value \\
\hline RSV & $>2 \mathrm{mg} / \mathrm{kg}$ & + & $1.4(0.4-5.2)$ & $0.19^{3}$ & $>2 \mathrm{mg} / \mathrm{kg}$ & +++ & $3.3(1.7-6.3)$ & $<0.001^{11}$ \\
\hline Influenza & $\geq 1 \mathrm{mg} / \mathrm{kg}$ & $+/-$ & $0.8(0.2-2.4)$ & $0.60^{46}$ & $\geq 1 \mathrm{mg} / \mathrm{kg}$ & $+1-$ & $1.1(0.3-3.5)$ & $0.87^{46}$ \\
\hline PIV & $>2 \mathrm{mg} / \mathrm{kg}$ & +++ & $4.6(1.2-17.0)$ & $0.02^{74}$ & $>2 \mathrm{mg} / \mathrm{kg}$ & +++ & $3.2(1.5-7.2)$ & $0.004^{13}$ \\
\hline \multirow[t]{2}{*}{ HMPV or RSV } & \multirow[t]{2}{*}{ No data } & & & & Any steroid & +++ & $5.0(1.8-14)$ & $0.002^{16}$ \\
\hline & & & & & $\geq 1 \mathrm{mg} / \mathrm{kg}$ & ++++ & $7.1(2.3-22)$ & $<0.001^{16}$ \\
\hline
\end{tabular}

Adapted from Waghmare et al. [163]

$R S V$ respiratory syncytial virus, $P I V$ parainfluenza virus, $H M P V$ human metapneumovirus, $H R$ hazard ratio

\section{Epidemiology}

Influenza is a significant cause of morbidity and mortality in transplant patients. In recipients of solid organ transplantation, up to $42 \%$ of URTIs and $48 \%$ of LRTIs may be due to influenza infection and the annual between $1 \%$ and 4\% [164]. During the 2009 H1N1 pandemic, mortality rates ranged from 0 to $8 \%$ in most case series [4] although one study reported a mortality rate of $21 \%$ among lung transplant recipients [165]. Of the organ transplants, lung transplant recipients appear to be at the highest risk; in one study, the incidence of influenza was 10-15 times higher in recipients of lung transplantation compared with recipients of other solid organs such as kidney or liver [166].

The incidence of influenza among HSCT ranges between $1 \%$ and $4 \%$ with $7-44 \%$ of such patients may develop LRTI. Death rates associated with influenza in HSCT recipients are higher than in SOT. Among patients with LRTI, mortality rates ranged from $15 \%$ to $28 \%$ and case fatality rates during the $2009 \mathrm{H} 1 \mathrm{~N} 1$ pandemic ranged from 0 to $38 \%$ [4]. The main risk factor for disease progression to LRTI was lymphopenia; allogeneic HSCT, infection during early posttransplant period, presence of graft-versus-host disease, myeloablative preparatory regimen, and delayed initiation of antiviral therapy were other risk factors $[1,11,12,167]$. Of interest, concomitant corticosteroid use has not been associ- ated with an increased risk for progression to LRTI, a need for mechanical ventilation, or infection associated death; however, patients given systemic higher doses $(\geq 1 \mathrm{mg} / \mathrm{kg})$ of corticosteroids may be predisposed to prolonged viral shedding $[11,168]$. The potential role of corticosteroids in influencing risk of progression to LRTI and mortality of influenza and other respiratory viral infections is summarized in Table 40.2 [163].

\section{Clinical Manifestations}

Clinical manifestations of influenza are similar to those in immunocompetent patients. In a multicenter cohort study of 242 organ transplant patients during the 2009 H1N1 pandemic, the most common presenting symptoms were cough $(91 \%)$, fever $(85 \%)$, myalgias $(51 \%)$, gastrointestinal symptoms $(44 \%)$, rhinorrhea $(43 \%)$, and sore throat (43\%) [169]. In a multicenter cohort study of 286 HSCT recipients during the $2009 \mathrm{H} 1 \mathrm{~N} 1$ pandemic, the most common presenting symptoms were cough (85\%), fever (81\%), rhinorrhea (49\%), myalgias (29\%), and sore throat (23\%) [170]. However, atypical presentations may occur in those with significant immunosuppression, which may include fever as the only presenting symptom or afebrile patient with rhinorrhea alone. It is speculated that corticosteroid use and blunting of the cytokine response associated with 
acute influenza infection in these patients may contribute to the reduction or absence of systemic symptoms in selected patients.

The primary complication of influenza infection in transplant patients is progression from URTI to LRTI which can lead to acute lung injury and death. Morbidity and mortality appear to be greatest among HSCT and lung transplant recipients. While diffuse or peribronchial ground-glass opacity is the typical radiographic appearance in patients with LRTI, centrilobular nodules and frank lower lobe consolidation can also be observed [171]. Coinfection with other viral, bacterial, or fungal pathogens may occur and was reported in $29 \%$ of patients in a multicenter study of SOT recipients with pandemic influenza A/H1N1 [172]. Compared to those with viral co-pathogens, patients with bacterial or fungal coinfections had worse outcomes [11, 172]. Although uncommon, influenza can also a cause a variety of extrapulmonary complications including myocarditis, myositis, encephalopathy, renal failure, severe diarrhea, and pneumomediastinum [166, 173, 174]. Virus-associated hemophagocytic syndrome has been reported as a severe complication of pandemic $\mathrm{H} 1 \mathrm{~N} 1$ leading to multiorgan failure [175]. As discussed previously, several studies suggest an association between RVIs including influenza and allograft rejection/BOS in the case of lung transplants, while others have not; a prospective study is needed to better characterize the impact of these infections on long-term sequelae [19, 44, 172, 176].

In healthy adults, seasonal influenza virus shedding ranges from 5 to 7 days and may extend beyond 1 week in hospitalized patients [177, 178] and even longer in transplant recipients. The median duration of viral shedding among allogeneic HSCT recipients was between 11 and 12 days compared to 1 week among recipients of autologous transplants $[11,179]$. Prolonged viral shedding beyond 2 weeks and, in some cases, for months has been described in HSCT recipient. Risk factors for prolonged viral shedding include the use of corticosteroids at dosages $\geq 1 \mathrm{mg} / \mathrm{kg}$ per day and use of bone marrow and cord blood versus peripheral blood stem cell.

\section{Diagnosis}

There are several methods available for detection of influenza including rapid antigen, direct immunofluorescence antibody (DFA), viral culture, and PCR. As for other respiratory viruses, molecular tests have largely replaced these other testing modalities. In a study evaluating test characteristics of four different diagnostic assays during the 2009 H1N1 pandemic, PCR was found to have the greatest sensitivity and specificity. Given their improved sensitivity and specificity over other methods, PCR or other nucleic acid-based detection assays are preferred for the diagnosis of influenza infection in this susceptible patient population. Multiplex PCRs have the added advantage of identifying other causes of respiratory viral infections as well.

\section{Treatment}

Currently, there are two major classes of antiviral agents with activity against influenza: adamantanes which block the viral M2 protein ion channel, thereby preventing fusion of the virus with host cell membranes, and neuraminidase inhibitors which prevent the release of progeny virus from infected cells. While the adamantanes, amantadine, and rimantadine are only active against influenza A, the neuraminidase inhibitors oseltamivir and zanamivir are active against both influenza A and B viruses, although reduced effectiveness of oseltamivir has occasionally been reported for influenza B virus [180]. The development of resistance to the adamantanes among influenza A virus has substantially limited their utility in clinical practice. Although 2008-2009 seasonal H1N1 remained susceptible to the adamantanes, resistance emerged among seasonal H3N2 in 2003 and was widespread among 2009 pandemic H1N1 viruses. Oseltamivir resistance first emerged in 2007 among seasonal H1N1 viruses and was described during the $2009 \mathrm{H} 1 \mathrm{~N} 1$ pandemic [181]. Oseltamivir resistance is primarily conferred by the $\mathrm{H} 275 \mathrm{Y}$ mutation which does not result in cross-resistance to zanamivir. PCR testing is available for the detection of the $\mathrm{H} 275 \mathrm{Y}$ mutation. In 2010, the S247 N mutation was detected in strains of 2009 pandemic H1N1 collected in Asia and was found to confer low to moderate oseltamivir and zanamivir resistance [182]. Otherwise, there has been very little zanamivir resistance reported to date, and thus, it is recommended for the treatment of oseltamivir-resistant influenza infection.

Because resistance patterns evolve over time, clinicians should become familiar with local patterns of influenza circulation in their communities throughout each influenza season and refer to the Centers for Disease Control and Prevention (CDC) influenza website (http://www.cdc.gov/flu) [183] for updated information regarding antiviral resistance and recommendations regarding antiviral use. In addition, antiviral resistance appears to occur more commonly among severely immunocompromised patients likely due to prolonged viral shedding [184, 185]. During the 2009 H1N1 pandemic, the majority of patients with oseltamivir-resistant virus reported to the CDC were HSCT recipients or patients who had a hematologic malignancy receiving chemo- or immunosuppressive therapy [186].

There have been no randomized clinical trials of antiviral therapy for influenza in transplant patients. All randomized trials have included healthy adult outpatients who were treated within $48 \mathrm{~h}$ after symptom onset and, in aggregate, demonstrate a reduction in duration of symptoms by $\sim 1$ day 
and time to return to normal activity [180]. Although further study is needed regarding the role of antiviral therapy $>48 \mathrm{~h}$ of symptom onset, the 2009 IDSA guidelines for management of seasonal influenza suggest that antiviral therapy initiated $>48 \mathrm{~h}$ after symptom onset may be beneficial in hospitalized patients based on a prospective cohort study [167, 180, 187]. Observational studies suggest that early antiviral therapy of HSCT recipients with influenza URTI is effective in preventing progression to LRTI [8, 11, 168, 179, 188]. Among SOT recipients, a multicenter study found that early antiviral therapy was associated with a lower incidence of hospitalization and likelihood of ICU admission as compared to delayed ( $>48 \mathrm{~h}$ after symptom onset) therapy [169]. Although antiviral therapy may have its greatest value when initiated early, it is felt that symptomatic transplant patients may benefit even beyond $48 \mathrm{~h}$ if they have evidence of viral replication, and in general, treatment of all symptomatic transplant patients is recommended regardless of the duration of symptoms [189-191].

The optimal dose and duration of antiviral therapy in transplant patients has not been established. Oseltamivir has been studied at doses of $75 \mathrm{mg}$ or $150 \mathrm{mg}$ twice daily in immunocompetent patients with seasonal influenza; there was no significant advantage of the higher dose although a slightly higher rate of adverse effects was observed [192, 193]. However, due to concerns over higher viral loads, prolonged viral shedding, and uncertain drug absorption particularly in those patients undergoing chemotherapy or with gastrointestinal graft-versus-host disease, some experts suggest using the higher dose in transplant patients particularly if absorption is uncertain, in those patients with severe LRTI or who are critically ill [189-191]. Based on clinical studies in healthy adults, the recommended duration of treatment of influenza in immunocompetent patients is 5 days [180].
However, transplant patients may need longer durations of therapy due to prolonged viral shedding. Some experts recommend treating all SOT recipients until viral replication has ceased; authors recommend checking PCR once a week and treat until negative [190, 191]. Others have suggested a 10-day course for HSCT recipients and extending treatment in those patients with pneumonia, ongoing symptoms, or viral shedding [189]. Resistance testing should be considered in those patients with persistent viral shedding or who progress despite antiviral therapy.

While most literature in transplant recipients has focused on oseltamivir, inhaled zanamivir appears to be a reasonable alternative. IV zanamivir is currently available for compassionate use, and there is limited published experience among transplant recipients where it has been used with some benefit among patients with oseltamivir-resistant influenza or severe disease [194].

Peramivir, a parenteral neuraminidase inhibitor, was FDA approved in 2014 for the treatment of uncomplicated influenza infection in adults who have been ill for $\leq 2$ days. There are limited data regarding the use of peramivir in transplant recipients. Of note, the $\mathrm{H} 275 \mathrm{Y}$ mutation which confers oseltamivir resistance also confers cross-resistance to peramivir.

There are currently no data that indicates a clear clinical benefit of combination antiviral therapy over single drug therapy. A randomized, double-blind, multicenter phase 2 trial found that combination antiviral therapy with oseltamivir, amantadine and ribavirin reduced day 3 viral shedding compared to oseltamivir monotherapy, but there was no difference in clinical outcomes including resolution of symptoms or fever or time to recovery after illness [195].

Table 40.3 summarizes antiviral options for treatment of influenza.

Table 40.3 Antiviral options for the treatment of influenza

\begin{tabular}{|c|c|c|c|c|}
\hline $\begin{array}{l}\text { Antiviral } \\
\text { agent }\end{array}$ & Dose & $\begin{array}{l}\text { Parenteral } \\
\text { formulation? }\end{array}$ & Side effects & Remarks \\
\hline Oseltamivir & $\begin{array}{l}75 \mathrm{mg} \text { PO } \\
\text { twice daily }\end{array}$ & Yes, investigational & $\begin{array}{l}\text { Gastrointestinal: nausea, vomiting, } \\
\text { diarrhea } \\
\text { Neurologic: confusion, delirium, } \\
\text { depressed consciousness (mostly reported } \\
\text { among Japanese adolescents and adults) }\end{array}$ & $\begin{array}{l}\text { Some experts recommend higher doses } \\
(150 \mathrm{mg} \text { PO BID) in transplant patients } \\
\text { who are critically ill with LRTI }\end{array}$ \\
\hline Zanamivir & $\begin{array}{l}2 \text { puffs } \\
(10 \mathrm{mg}) \\
\text { inhaled twice } \\
\text { daily }\end{array}$ & Yes, investigational & $\begin{array}{l}\text { Bronchospasm, cough, headache, } \\
\text { dizziness, sinusitis, nausea, diarrhea }\end{array}$ & Little cross-resistance with oseltamivir \\
\hline Peramivir & $\begin{array}{l}600 \mathrm{mg} \text { IV } \\
\text { once daily }\end{array}$ & $\begin{array}{l}\text { Yes (only available as } \\
\text { parenteral } \\
\text { formulation) }\end{array}$ & $\begin{array}{l}\text { Gastrointestinal: nausea, vomiting, } \\
\text { diarrhea } \\
\text { Neutropenia }\end{array}$ & Cross-resistance with oseltamivir exists. \\
\hline Amantadine & $\begin{array}{l}100 \mathrm{mg} \text { PO } \\
\text { twice daily }\end{array}$ & No & $\begin{array}{l}\text { Neurologic: insomnia, lethargy, inability } \\
\text { to concentrate, dizziness } \\
\text { Gastrointestinal: nausea }\end{array}$ & $\begin{array}{l}\text { No longer routinely recommended due to } \\
\text { high incidence of resistant influenza unless } \\
\text { circulating strain known to be susceptible }\end{array}$ \\
\hline Rimantadine & $\begin{array}{l}100 \mathrm{mg} \text { PO } \\
\text { twice daily }\end{array}$ & No & $\begin{array}{l}\text { Gastrointestinal } \\
\text { Neurologic (less common than } \\
\text { amantadine): lightheadedness, insomnia, } \\
\text { inability to concentrate, nervousness }\end{array}$ & $\begin{array}{l}\text { No longer routinely recommended due to } \\
\text { high incidence of resistant influenza unless } \\
\text { circulating strain known to be susceptible }\end{array}$ \\
\hline
\end{tabular}




\section{Prevention}

Annual influenza vaccination is a key component of infection prevention among HSCT and SOT recipients. There are several types of influenza vaccines: standard-dose inactivated influenza vaccines (IIV), available either as a trivalent or quadrivalent injection, high-dose IIV (available as a trivalent injection), live attenuated influenza vaccine (LAIV), intradermal IIV, and recombinant egg-free IIV. All vaccines are modified annually based on the anticipated circulating strains during the upcoming influenza season. The LAIV is contraindicated in immunocompromised patients and should not be used in transplant recipients. The intradermal IIV has not been evaluated in transplant recipients.

For HSCT recipients, influenza vaccination is recommended $\geq 6$ months post-transplant and beginning 4 months following transplant if there is a community influenza outbreak [196]. If the vaccine is administered earlier than 6 months after HSCT, a second dose should be considered. The timing of vaccine administration appears to predict response with one study demonstrating that influenza immunization at least 6 months after HCT was $80 \%$ effective in preventing influenza [197]. The high-dose trivalent IIV is FDA approved for individuals $\geq 65$ years of age and was found in a multicenter randomized clinical trial to induce higher antibody responses and improved protection against influenza compared to standard dose IIV [198]. In a phase I trial, HSCT recipients randomized to receive high-dose trivalent IIV had evidence of greater immunogenicity when compared to those receiving standard-dose trivalent IIV [199]. There was a higher frequency of injection site reactions, but most were mild. There are ongoing studies to further evaluate the role of high-dose IIV in HSCT.

For SOT recipients, influenza vaccination is recommended 3-6 months after transplant [164]. The immunogenicity of influenza vaccine following SOT is variable depending on the type of transplant, time from transplant, and immunosuppressive regimens. Among SOT recipients, overall responses based on seroprotection or seroconversion have ranged from $15 \%$ to $93 \%$ with greater responses observed several years after kidney transplant and lower responses seen in lung transplant [164]. Although there is a theoretical concern that influenza immunization may be associated with early allograft rejection or allosensitization of patients after transplant, this has not been observed in clinical trials [200]. In a randomized, double-blind trial of 172 SOT recipients, high-dose influenza vaccine demonstrated significantly better immunogenicity than the standard-dose vaccine [201]; no increased risk of rejection was reported although the study was not powered to address this outcome.

Immunization of health care workers and household contacts of transplant recipients is a critical component of influenza prevention and is strongly recommended in published guidelines [147, 164]. A systematic review suggests that vaccination of healthcare workers reduces influenzalike illness and all-cause mortality in the elderly [202]. Due to the theoretical risk of transmission of LAIV, the CDC recommends that IIV not be used for household members and health care workers who have close contact with severely immunosuppressed patients such as recipient of hematopoietic stem cell allograft transplantation during those periods in which the patient requires care in a protective environment. Those persons who receive LAIV should avoid providing care for and contact with such patients for 7 days after vaccination.

Although influenza vaccination is the primary tool for influenza prevention, antiviral chemoprophylaxis may be considered as a prevention strategy in selected situations. The 2009 IDSA Guidelines for Management of Seasonal Influenza recommends consideration of antiviral chemoprophylaxis in high-risk patients during the 2 weeks after vaccination before an adequate immune response develops if influenza is circulating in the community [180]. It should also be considered among transplant recipients following exposure within the previous $48 \mathrm{~h}$ to an individual with influenza, particularly among those for whom the vaccine is contraindicated, unavailable, or expected to have low effectiveness such as patients with severe immune suppression. The choice of chemoprophylactic agent depends on the susceptibility pattern of the circulating influenza strain.

\section{Human Coronaviruses (HCoV) and Human Rhinoviruses (HRV)}

\section{Epidemiology}

HRVs and HCoVs are also common causes of RVIs in human, classified into the Picornaviridiae family (genus Enterovirus) and the Coronaviriae family, respectively. Approximately 100 serotypes of HRV have been identified. In comparison, $\mathrm{HCoV}-229 \mathrm{E}$ and $\mathrm{HCoV}-\mathrm{OC} 43$ were the only two known HCoVs for $>40$ years. In 2004, a new HCoV was identified as the causative agent of the outbreak of Severe Acute Respiratory Syndrome (SARS) and was named SARS-CoV. Subsequently, two other new HCoVs, NL63 and HKU1, were discovered in 2004 and 2005, respectively. In the latter part of 2012, another novel CoV was identified as the cause of severe respiratory illness in two adults from the Middle East [203] and was termed Middle East respiratory syndrome coronavirus (MERS-CoV). Similar to SARS-CoV, this virus can also cause severe, life-threatening disease. The ability of these emerging $\mathrm{HCoVs}$ to cause major outbreaks can be a potential threat to global public health and economy [204]. 


\section{HCoV and HRV in Transplantation}

In immunocompetent hosts, $\mathrm{HRV}$ s and $\mathrm{HCoVs}$ usually cause URTIs, but HCoVs can also cause croup, wheezing, as well as pneumonia, which can be severe with significant mortality, as in the case of SARS. The significance of HRV and $\mathrm{HCoV}$ in transplant populations has not been well established. According to a prospective study of HSCT recipients [5], infection with these viruses appears common in the first 100 days after allogeneic transplant, with day 100 cumulative incidence estimated as $22 \%$ for HRV and $11 \%$ for HCoV. HRV infection was associated with URTI signs and symptoms, but $\mathrm{HCoV}$ infection was asymptomatic. More than half of the infected patients had prolonged viral shedding for more than 3 weeks, and about $13 \%$ shed virus for more than 3 months [5]; only a few patients developed LRTI in that study. Fatal pneumonia associated with HRV and $\mathrm{HCoV}$ have been reported among HSCT recipients [205-207]. Recent studies suggested that HRV and HCoV LRTI with viral detection in the BAL are associated with mortality rates similar to those seen with RSV, PIV, or influenza viruses [10, 208].

For SOT, HRV and $\mathrm{HCoV}$ are frequently isolated among lung transplant patients $[23,25,28]$, but a majority of these patients can be asymptomatic, according to a prospective surveillance study [28]. As discussed previously, RVI can increase the risk for developing acute rejection and/or BOS even with asymptomatic infections [23, 25, 28], but whether $\mathrm{HRV}$ or $\mathrm{HCoV}$ infection confer the same level of risk as compared to the paramyxoviruses or influenza cannot be delineated from these studies.

Currently, there are no specific agents licensed for the treatment of $\mathrm{HRV}$ and $\mathrm{HCoV}$, but antiviral therapy for enteroviruses is under intense research.

\section{Conclusions and Future Directions}

Respiratory viral infections are common and associated with significant morbidity and mortality among patients undergoing hematopoietic stem cells and solid organ transplantation. The optimal management of these infections is limited by insufficient randomized treatment data as well as a limited new and novel antiviral drugs being investigated for potential clinical use. Large, preferably multicenter prospective, randomized trials are essential to (1) assess preferred therapy for life-threatening infections such as RSV, (2) define the role of combination antivirals for influenza virus infections, and (3) determine the use of adjunctive immunomodulatory therapy and/or corticosteroids in the management of these infections among the highly susceptible transplant population. The evaluation of novel long-lasting potent monoclonal antibodies for prevention may be warranted.

\section{References}

1. Schiffer JT, Kirby K, Sandmaier B, Storb R, Corey L, Boeckh $\mathrm{M}$. Timing and severity of community acquired respiratory virus infections after myeloablative versus non-myeloablative hematopoietic stem cell transplantation. Haematologica. 2009;94:1101-8.

2. Nichols WG, Corey L, Gooley T, Davis C, Boeckh M. Parainfluenza virus infections after hematopoietic stem cell transplantation: risk factors, response to antiviral therapy, and effect on transplant outcome. Blood. 2001;98:573-8.

3. Weinberg A, Lyu DM, Li S, Marquesen J, Zamora MR. Incidence and morbidity of human metapneumovirus and other communityacquired respiratory viruses in lung transplant recipients. Transpl Infect Dis. 2010;12:330-5.

4. Renaud C, Campbell AP. Changing epidemiology of respiratory viral infections in hematopoietic cell transplant recipients and solid organ transplant recipients. Curr Opin Infect Dis. 2011;24: 333-43.

5. Milano F, Campbell AP, Guthrie KA, et al. Human rhinovirus and coronavirus detection among allogeneic hematopoietic stem cell transplantation recipients. Blood. 2010;115:2088-94.

6. Nichols WG, Gooley T, Boeckh M. Community-acquired respiratory syncytial virus and parainfluenza virus infections after hematopoietic stem cell transplantation: the Fred Hutchinson Cancer Research Center experience. Biol Blood Marrow Transplant. 2001;7(Suppl):11S-5S.

7. Champlin RE, Whimbey E. Community respiratory virus infections in bone marrow transplant recipients: the M.D. Anderson Cancer Center experience. Biol Blood Marrow Transplant. 2001;7(Suppl):8S-10S.

8. Chemaly RF, Ghosh S, Bodey GP, et al. Respiratory viral infections in adults with hematologic malignancies and human stem cell transplantation recipients: a retrospective study at a major cancer center. Medicine (Baltimore). 2006;85:278-87.

9. Whimbey E, Champlin RE, Couch RB, et al. Community respiratory virus infections among hospitalized adult bone marrow transplant recipients. Clin Infect Dis. 1996;22:778-82.

10. Seo S, Waghmare A, Scott EM, et al. Human rhinovirus detection in the lower respiratory tract of hematopoietic cell transplant recipients: association with mortality. Haematologica. 2017;102:1120-30.

11. Nichols WG, Guthrie KA, Corey L, Boeckh M. Influenza infections after hematopoietic stem cell transplantation: risk factors, mortality, and the effect of antiviral therapy. Clin Infect Dis. 2004;39: 1300-6.

12. Ljungman $\mathrm{P}$, Ward $\mathrm{KN}$, Crooks BN, et al. Respiratory virus infections after stem cell transplantation: a prospective study from the infectious diseases working party of the European Group for Blood and Marrow Transplantation. Bone Marrow Transplant. 2001;28:479-84.

13. Kim YJ, Guthrie KA, Waghmare A, et al. Respiratory syncytial virus in hematopoietic cell transplant recipients: factors determining progression to lower respiratory tract disease. J Infect Dis. 2014;209:1195-204.

14. Seo S, Xie H, Leisenring WM, et al. Risk factors for parainfluenza virus lower respiratory tract disease after hematopoietic cell transplantation. Biol Blood Marrow Transplant. 2019;25(1):163-71.

15. Shah DP, Ghantoji SS, Ariza-Heredia EJ, et al. Immunodeficiency scoring index to predict poor outcomes in hematopoietic cell transplant recipients with RSV infections. Blood. 2014;123:3263-8.

16. Billings JL, Hertz MI, Wendt $\mathrm{CH}$. Community respiratory virus infections following lung transplantation. Transpl Infect Dis. 2001;3:138-48.

17. Palmer SM Jr, Henshaw NG, Howell DN, Miller SE, Davis RD, Tapson VF. Community respiratory viral infection in adult lung transplant recipients. Chest. 1998;113:944-50. 
18. Vilchez R, McCurry K, Dauber J, et al. Influenza and parainfluenza respiratory viral infection requiring admission in adult lung transplant recipients. Transplantation. 2002;73:1075-8.

19. Lopez-Medrano F, Aguado JM, Lizasoain M, et al. Clinical implications of respiratory virus infections in solid organ transplant recipients: a prospective study. Transplantation. 2007;84:851-6.

20. Dudek AZ, Mahaseth H, DeFor TE, Weisdorf DJ. Bronchiolitis obliterans in chronic graft-versus-host disease: analysis of risk factors and treatment outcomes. Biol Blood Marrow Transplant. 2003;9:657-66.

21. Belperio JA, Lake K, Tazelaar H, Keane MP, Strieter RM, Lynch JP 3rd. Bronchiolitis obliterans syndrome complicating lung or heart-lung transplantation. Semin Respir Crit Care Med. 2003;24:499-530.

22. Fishman JA. Infection in solid-organ transplant recipients. N Engl J Med. 2007;357:2601-14.

23. Gottlieb J, Schulz TF, Welte T, et al. Community-acquired respiratory viral infections in lung transplant recipients: a single season cohort study. Transplantation. 2009;87:1530-7.

24. Khalifah AP, Hachem RR, Chakinala MM, et al. Respiratory viral infections are a distinct risk for bronchiolitis obliterans syndrome and death. Am J Respir Crit Care Med. 2004;170:181-7.

25. Kumar D, Erdman D, Keshavjee S, et al. Clinical impact of community-acquired respiratory viruses on bronchiolitis obliterans after lung transplant. Am J Transplant. 2005;5:2031-6.

26. Milstone AP, Brumble LM, Barnes J, et al. A single-season prospective study of respiratory viral infections in lung transplant recipients. Eur Respir J. 2006;28:131-7.

27. Husain S, Singh N. Bronchiolitis obliterans and lung transplantation: evidence for an infectious etiology. Semin Respir Infect. 2002; 17:310-4.

28. Kumar D, Husain S, Chen MH, et al. A prospective molecular surveillance study evaluating the clinical impact of communityacquired respiratory viruses in lung transplant recipients. Transplantation. 2010;89:1028-33.

29. Liu V, Dhillon GS, Weill D. A multi-drug regimen for respiratory syncytial virus and parainfluenza virus infections in adult lung and heart-lung transplant recipients. Transpl Infect Dis. 2010;12:38-44.

30. Fisher CE, Preiksaitis CM, Lease ED, et al. Symptomatic respiratory virus infection and chronic lung allograft dysfunction. Clin Infect Dis. 2016;62:313-9.

31. Erard V, Chien JW, Kim HW, et al. Airflow decline after myeloablative allogeneic hematopoietic cell transplantation: the role of community respiratory viruses. J Infect Dis. 2006;193:1619-25.

32. Versluys AB, Rossen JW, van Ewijk B, Schuurman R, Bierings $\mathrm{MB}$, Boelens JJ. Strong association between respiratory viral infection early after hematopoietic stem cell transplantation and the development of life-threatening acute and chronic alloimmune lung syndromes. Biol Blood Marrow Transplant. 2010;16:782-91.

33. Au BK, Au MA, Chien JW. Bronchiolitis obliterans syndrome epidemiology after allogeneic hematopoietic cell transplantation. Biol Blood Marrow Transplant. 2011;17:1072-8.

34. Chien JW, Duncan S, Williams KM, Pavletic SZ. Bronchiolitis obliterans syndrome after allogeneic hematopoietic stem cell transplantation-an increasingly recognized manifestation of chronic graft-versus-host disease. Biol Blood Marrow Transplant. 2010;16:S106-14.

35. Gerna G, Vitulo P, Rovida F, et al. Impact of human metapneumovirus and human cytomegalovirus versus other respiratory viruses on the lower respiratory tract infections of lung transplant recipients. J Med Virol. 2006;78:408-16.

36. Larcher C, Geltner C, Fischer H, Nachbaur D, Muller LC, Huemer HP. Human metapneumovirus infection in lung transplant recipients: clinical presentation and epidemiology. J Heart Lung Transplant. 2005;24:1891-901.
37. McCurdy LH, Milstone A, Dummer S. Clinical features and outcomes of paramyxoviral infection in lung transplant recipients treated with ribavirin. J Heart Lung Transplant. 2003;22:745-53.

38. Hall CB. Respiratory syncytial virus and parainfluenza virus. $\mathrm{N}$ Engl J Med. 2001;344:1917-28.

39. Boyce TG, Mellen BG, Mitchel EF Jr, Wright PF, Griffin MR. Rates of hospitalization for respiratory syncytial virus infection among children in medicaid. J Pediatr. 2000;137:865-70.

40. Duncan CB, Walsh EE, Peterson DR, Lee FE, Falsey AR. Risk factors for respiratory failure associated with respiratory syncytial virus infection in adults. J Infect Dis. 2009;200:1242-6.

41. Walsh EE, Peterson DR, Falsey AR. Risk factors for severe respiratory syncytial virus infection in elderly persons. J Infect Dis. 2004;189:233-8.

42. CDC. Respiratory syncytial virus activity - United States, July 2008-December 2009. MMWR Morb Mortal Wkly Rep. 2010;59:230-3.

43. Hall CB, Long CE, Schnabel KC. Respiratory syncytial virus infections in previously healthy working adults. Clin Infect Dis. 2001;33:792-6.

44. Kim YJ, Boeckh M, Englund JA. Community respiratory virus infections in immunocompromised patients: hematopoietic stem cell and solid organ transplant recipients, and individuals with human immunodeficiency virus infection. Semin Respir Crit Care Med. 2007;28:222-42.

45. Weigt SS, Gregson AL, Deng JC, Lynch JP 3rd, Belperio JA. Respiratory viral infections in hematopoietic stem cell and solid organ transplant recipients. Semin Respir Crit Care Med. 2011;32:471-93.

46. Boeckh M. The challenge of respiratory virus infections in hematopoietic cell transplant recipients. Br J Haematol. 2008;143:455-67.

47. Shah JN, Chemaly RF. Management of RSV infections in adult recipients of hematopoietic stem cell transplantation. Blood. 2011;117:2755-63.

48. Hynicka LM, Ensor CR. Prophylaxis and treatment of respiratory syncytial virus in adult immunocompromised patients. Ann Pharmacother. 2012;46:558-66.

49. Waghmare A, Xie H, Kimball L, et al. Supplemental oxygen-free days in hematopoietic cell transplant recipients with respiratory syncytial virus. J Infect Dis. 2017;216:1235-44.

50. Anderson NW, Binnicker MJ, Harris DM, et al. Morbidity and mortality among patients with respiratory syncytial virus infection: a 2-year retrospective review. Diagn Microbiol Infect Dis. 2016;85:367-71.

51. Foolad F, Aitken SL, Shigle TL, et al. Oral versus aerosolized ribavirin for the treatment of respiratory syncytial virus infections in hematopoietic cell transplantation recipients. Clin Infect Dis. 2018. https://doi.org/10.1093/cid/ciy760. [Epub ahead of print].

52. Pilie P, Werbel WA, Riddell J, Shu X, Schaubel D, Gregg KS. Adult patients with respiratory syncytial virus infection: impact of solid organ and hematopoietic stem cell transplantation on outcomes. Transpl Infect Dis. 2015;17:551-7.

53. Waghmare A, Campbell AP, Xie H, et al. Respiratory syncytial virus lower respiratory disease in hematopoietic cell transplant recipients: viral RNA detection in blood, antiviral treatment, and clinical outcomes. Clin Infect Dis. 2013;57:1731-41.

54. Shah DP, Ghantoji SS, Shah JN, et al. Impact of aerosolized ribavirin on mortality in 280 allogeneic haematopoietic stem cell transplant recipients with respiratory syncytial virus infections. J Antimicrob Chemother. 2013;68:1872-80.

55. Martino R, Porras RP, Rabella N, et al. Prospective study of the incidence, clinical features, and outcome of symptomatic upper and lower respiratory tract infections by respiratory viruses in adult recipients of hematopoietic stem cell transplants for hematologic malignancies. Biol Blood Marrow Transplant. 2005;11:781-96. 
56. Ghosh S, Champlin RE, Englund J, et al. Respiratory syncytial virus upper respiratory tract illnesses in adult blood and marrow transplant recipients: combination therapy with aerosolized ribavirin and intravenous immunoglobulin. Bone Marrow Transplant. 2000;25:751-5.

57. Ariza-Heredia EJ, Fishman JE, Cleary T, Smith L, Razonable RR, Abbo L. Clinical and radiological features of respiratory syncytial virus in solid organ transplant recipients: a single-center experience. Transpl Infect Dis. 2012;14:64-71.

58. Uckay I, Gasche-Soccal PM, Kaiser L, et al. Low incidence of severe respiratory syncytial virus infections in lung transplant recipients despite the absence of specific therapy. J Heart Lung Transplant. 2010;29:299-305.

59. Hall CB, McBride JT, Walsh EE, et al. Aerosolized ribavirin treatment of infants with respiratory syncytial viral infection. A randomized double-blind study. N Engl J Med. 1983;308:1443-7.

60. Graci JD, Cameron CE. Quasispecies, error catastrophe, and the antiviral activity of ribavirin. Virology. 2002;298:175-80.

61. Tam RC, Lau JY, Hong Z. Mechanisms of action of ribavirin in antiviral therapies. Antivir Chem Chemother. 2001;12:261-72.

62. Sookoian S, Castano G, Flichman D, Cello J. Effects of ribavirin on cytokine production of recall antigens and phytohemaglutininstimulated peripheral blood mononuclear cells. (Inhibitory effects of ribavirin on cytokine production). Ann Hepatol. 2004;3 104-7.

63. Englund JA, Piedra PA, Ahn YM, Gilbert BE, Hiatt P. High-dose, short-duration ribavirin aerosol therapy compared with standard ribavirin therapy in children with suspected respiratory syncytial virus infection. J Pediatr. 1994;125:635-41.

64. Chemaly RF, Hanmod SS, Rathod DB, et al. The characteristics and outcomes of parainfluenza virus infections in 200 patients with leukemia or recipients of hematopoietic stem cell transplantation. Blood. 2012;119:2738-45; quiz 969.

65. Chemaly RF, Torres HA, Munsell MF, et al. An adaptive randomized trial of an Intermittent Dosing Schedule of Aerosolized Ribavirin in patients with cancer and respiratory syncytial virus infection. J Infect Dis. 2012;206:1367-71.

66. Hirsch HH, Martino R, Ward KN, Boeckh M, Einsele H, Ljungman P. Fourth European Conference on Infections in Leukaemia (ECIL4): guidelines for diagnosis and treatment of human respiratory syncytial virus, parainfluenza virus, metapneumovirus, rhinovirus, and coronavirus. Clin Infect Dis. 2013;56:258-66.

67. Newborn AAoPCoIDaCoFa. Prevention of respiratory syncytial virus infections: indications for the use of palivizumab and update on the use of RSV-IGIV. American Academy of Pediatrics Committee on Infectious Diseases and Committee of Fetus and Newborn. Pediatrics. 1998;102:1211-6.

68. Boeckh M, Berrey MM, Bowden RA, Crawford SW, Balsley J, Corey L. Phase 1 evaluation of the respiratory syncytial virusspecific monoclonal antibody palivizumab in recipients of hematopoietic stem cell transplants. J Infect Dis. 2001;184:350-4.

69. Boeckh M, Englund J, Li Y, et al. Randomized controlled multicenter trial of aerosolized ribavirin for respiratory syncytial virus upper respiratory tract infection in hematopoietic cell transplant recipients. Clin Infect Dis. 2007;44:245-9.

70. Small TN, Casson A, Malak SF, et al. Respiratory syncytial virus infection following hematopoietic stem cell transplantation. Bone Marrow Transplant. 2002;29:321-7.

71. McCoy D, Wong E, Kuyumjian AG, Wynd MA, Sebti R, Munk GB. Treatment of respiratory syncytial virus infection in adult patients with hematologic malignancies based on an institutionspecific guideline. Transpl Infect Dis. 2011;13:117-21.

72. Tsitsikas DA, Oakervee H, Cavenagh JD, Gribben J, Agrawal SG, Mattes FM. Treatment of respiratory syncytial virus infection in haemopoietic stem cell transplant recipients with aerosolized riba- virin and the humanized monoclonal antibody palivizumab: a single centre experience. Br J Haematol. 2009;146:574-6.

73. Seo S, Campbell AP, Xie H, et al. Outcome of respiratory syncytial virus lower respiratory tract disease in hematopoietic cell transplant recipients receiving aerosolized ribavirin: significance of stem cell source and oxygen requirement. Biol Blood Marrow Transplant. 2013;19:589-96.

74. de Fontbrune FS, Robin M, Porcher R, et al. Palivizumab treatment of respiratory syncytial virus infection after allogeneic hematopoietic stem cell transplantation. Clin Infect Dis. 2007;45:1019-24.

75. Chemaly RF, Aitken SL, Wolfe CR, Jain R, Boeckh MJ. Aerosolized ribavirin: the most expensive drug for pneumonia. Transpl Infect Dis. 2016;18:634-6.

76. Khanna N, Widmer AF, Decker M, et al. Respiratory syncytial virus infection in patients with hematological diseases: singlecenter study and review of the literature. Clin Infect Dis. 2008;46: 402-12.

77. Marcelin JR, Wilson JW, Razonable RR, Mayo Clinic HO. Transplant Infectious Diseases S. Oral ribavirin therapy for respiratory syncytial virus infections in moderately to severely immunocompromised patients. Transpl Infect Dis. 2014;16:242-50.

78. Trang TP, Whalen M, Hilts-Horeczko A, Doernberg SB, Liu C. Comparative effectiveness of aerosolized versus oral ribavirin for the treatment of respiratory syncytial virus infections: a singlecenter retrospective cohort study and review of the literature. Transpl Infect Dis. 2018;20:e12844.

79. Beaird OE, Freifeld A, Ison MG, et al. Current practices for treatment of respiratory syncytial virus and other non-influenza respiratory viruses in high-risk patient populations: a survey of institutions in the Midwestern Respiratory Virus Collaborative. Transpl Infect Dis. 2016;18:210-5.

80. Luo YH, Huang CY, Yang KY, Lee YC. Inhaled ribavirin therapy in adult respiratory syncytial virus-induced acute respiratory distress syndrome. Arch Bronconeumol. 2011;47:315-7.

81. Pelaez A, Lyon GM, Force SD, et al. Efficacy of oral ribavirin in lung transplant patients with respiratory syncytial virus lower respiratory tract infection. J Heart Lung Transplant. 2009;28:67-71.

82. Fuehner T, Dierich M, Duesberg C, et al. Single-centre experience with oral ribavirin in lung transplant recipients with paramyxovirus infections. Antivir Ther. 2011;16:733-40.

83. Li L, Avery R, Budev M, Mossad S, Danziger-Isakov L. Oral versus inhaled ribavirin therapy for respiratory syncytial virus infection after lung transplantation. J Heart Lung Transplant. 2012;31(8):839-44.

84. Glanville AR, Scott AI, Morton JM, et al. Intravenous ribavirin is a safe and cost-effective treatment for respiratory syncytial virus infection after lung transplantation. J Heart Lung Transplant. 2005;24:2114-9.

85. Gottlieb J, Torres F, Haddad T, et al. Respiratory syncytial virus (RSV) in lung transplant (LT) recipients. J Heart Lung Transplant. 2018:37:S155.

86. Elizaga J, Olavarria E, Apperley J, Goldman J, Ward K. Parainfluenza virus 3 infection after stem cell transplant: relevance to outcome of rapid diagnosis and ribavirin treatment. Clin Infect Dis. 2001;32:413-8.

87. Lewis VA, Champlin R, Englund J, et al. Respiratory disease due to parainfluenza virus in adult bone marrow transplant recipients. Clin Infect Dis. 1996;23:1033-7.

88. Vilchez RA, Dauber J, McCurry K, Iacono A, Kusne S. Parainfluenza virus infection in adult lung transplant recipients: an emergent clinical syndrome with implications on allograft function. Am J Transplant. 2003;3:116-20.

89. Whimbey E, Vartivarian SE, Champlin RE, Elting LS, Luna M, Bodey GP. Parainfluenza virus infection in adult bone marrow transplant recipients. Eur J Clin Microbiol Infect Dis. 1993;12:699-701. 
90. Ustun C, Slaby J, Shanley RM, et al. Human parainfluenza virus infection after hematopoietic stem cell transplantation: risk factors, management, mortality, and changes over time. Biol Blood Marrow Transplant. 2012;18:1580-8.

91. Peck AJ, Englund JA, Kuypers J, et al. Respiratory virus infection among hematopoietic cell transplant recipients: evidence for asymptomatic parainfluenza virus infection. Blood. 2007;110:1681-8.

92. Billings JL, Hertz MI, Savik K, Wendt CH. Respiratory viruses and chronic rejection in lung transplant recipients. J Heart Lung Transplant. 2002;21:559-66.

93. Garbino J, Gerbase MW, Wunderli W, et al. Respiratory viruses and severe lower respiratory tract complications in hospitalized patients. Chest. 2004;125:1033-9.

94. Maziarz RT, Sridharan P, Slater S, et al. Control of an outbreak of human parainfluenza virus 3 in hematopoietic stem cell transplant recipients. Biol Blood Marrow Transplant. 2010;16:192-8.

95. Wendt $\mathrm{CH}$, Weisdorf DJ, Jordan MC, Balfour HH Jr, Hertz MI. Parainfluenza virus respiratory infection after bone marrow transplantation. N Engl J Med. 1992;326:921-6.

96. Chakrabarti S, Collingham KE, Holder K, Fegan CD, Osman H, Milligan DW. Pre-emptive oral ribavirin therapy of paramyxovirus infections after haematopoietic stem cell transplantation: a pilot study. Bone Marrow Transplant. 2001;28:759-63.

97. Shima T, Yoshimoto G, Nonami A, et al. Successful treatment of parainfluenza virus 3 pneumonia with oral ribavirin and methylprednisolone in a bone marrow transplant recipient. Int J Hematol. 2008;88:336-40.

98. Chakrabarti S, Collingham KE, Holder K, Oyaide S, Pillay D, Milligan DW. Parainfluenza virus type 3 infections in hematopoetic stem cell transplant recipients: response to ribavirin therapy. Clin Infect Dis. 2000;31:1516-8.

99. Cobian L, Houston S, Greene J, Sinnott JT. Parainfluenza virus respiratory infection after heart transplantation: successful treatment with ribavirin. Clin Infect Dis. 1995;21:1040-1.

100. Wright JJ, O'Driscoll G. Treatment of parainfluenza virus 3 pneumonia in a cardiac transplant recipient with intravenous ribavirin and methylprednisolone. J Heart Lung Transplant. 2005;24:343-6.

101. Park SY, Sung H, Park KT, et al. Parainfluenza virus 3 pneumonia in a kidney transplant recipient. Transpl Infect Dis. 2009;11:333-6.

102. Chen YB, Driscoll JP, McAfee SL, et al. Treatment of parainfluenza 3 infection with DAS181 in a patient after allogeneic stem cell transplantation. Clin Infect Dis. 2011;53:e77-80.

103. Guzman-Suarez BB, Buckley MW, Gilmore ET, et al. Clinical potential of DAS181 for treatment of parainfluenza-3 infections in transplant recipients. Transpl Infect Dis. 2012;14(4):427-33.

104. Drozd DR, Limaye AP, Moss RB, et al. DAS181 treatment of severe parainfluenza type 3 pneumonia in a lung transplant recipient. Transpl Infect Dis. 2013;15:E28-32.

105. Chalkias S, Mackenzie MR, Gay C, et al. DAS181 treatment of hematopoietic stem cell transplant patients with parainfluenza virus lung disease requiring mechanical ventilation. Transpl Infect Dis. 2014;16:141-4.

106. Salvatore M, Satlin MJ, Jacobs SE, et al. DAS181 for treatment of Parainfluenza virus infections in Hematopoietic stem cell transplant recipients at a single center. Biol Blood Marrow Transplant. 2016;22:965-70.

107. van den Hoogen BG, de Jong JC, Groen J, et al. A newly discovered human pneumovirus isolated from young children with respiratory tract disease. Nat Med. 2001;7:719-24.

108. Kroll JL, Weinberg A. Human metapneumovirus. Semin Respir Crit Care Med. 2011;32:447-53.

109. Biacchesi S, Skiadopoulos MH, Boivin G, et al. Genetic diversity between human metapneumovirus subgroups. Virology. 2003;315:1-9.
110. Williams JV, Harris PA, Tollefson SJ, et al. Human metapneumovirus and lower respiratory tract disease in otherwise healthy infants and children. N Engl J Med. 2004;350:443-50.

111. Falsey AR. Human metapneumovirus infection in adults. Pediatr Infect Dis J. 2008;27:S80-3.

112. Falsey AR, Erdman D, Anderson LJ, Walsh EE. Human metapneumovirus infections in young and elderly adults. J Infect Dis. 2003;187:785-90.

113. Walsh EE, Peterson DR, Falsey AR. Human metapneumovirus infections in adults: another piece of the puzzle. Arch Intern Med. 2008;168:2489-96.

114. Debur MC, Vidal LR, Stroparo E, et al. Human metapneumovirus infection in hematopoietic stem cell transplant recipients. Transpl Infect Dis. 2010;12:173-9.

115. Englund JA, Boeckh M, Kuypers J, et al. Brief communication: fatal human metapneumovirus infection in stem-cell transplant recipients. Ann Intern Med. 2006;144:344-9.

116. Williams JV, Martino R, Rabella N, et al. A prospective study comparing human metapneumovirus with other respiratory viruses in adults with hematologic malignancies and respiratory tract infections. J Infect Dis. 2005;192:1061-5.

117. Oliveira R, Machado A, Tateno A, Boas LV, Pannuti C, Machado C. Frequency of human metapneumovirus infection in hematopoietic SCT recipients during 3 consecutive years. Bone Marrow Transplant. 2008;42:265-9.

118. Shah DP, Shah PK, Azzi JM, El Chaer F, Chemaly RF. Human metapneumovirus infections in hematopoietic cell transplant recipients and hematologic malignancy patients: A systematic review. Cancer Lett. 2016;379:100-6.

119. Seo S, Gooley TA, Kuypers JM, et al. Human metapneumovirus infections following hematopoietic cell transplantation: Factors associated with disease progression. Clin Infect Dis. 2016;63:178-85.

120. Hopkins P, McNeil K, Kermeen F, et al. Human metapneumovirus in lung transplant recipients and comparison to respiratory syncytial virus. Am J Respir Crit Care Med. 2008;178:876-81.

121. Wyde PR, Chetty SN, Jewell AM, Boivin G, Piedra PA. Comparison of the inhibition of human metapneumovirus and respiratory syncytial virus by ribavirin and immune serum globulin in vitro. Antivir Res. 2003;60:51-9.

122. Hamelin ME, Prince GA, Boivin G. Effect of ribavirin and glucocorticoid treatment in a mouse model of human metapneumovirus infection. Antimicrob Agents Chemother. 2006;50:774-7.

123. Bonney D, Razali H, Turner A, Will A. Successful treatment of human metapneumovirus pneumonia using combination therapy with intravenous ribavirin and immune globulin. Br J Haematol. 2009;145:667-9.

124. Shachor-Meyouhas Y, Ben-Barak A, Kassis I. Treatment with oral ribavirin and IVIG of severe human metapneumovirus pneumonia (HMPV) in immune compromised child. Pediatr Blood Cancer. 2011:57:350-1.

125. Shahda S, Carlos WG, Kiel PJ, Khan BA, Hage CA. The human metapneumovirus: a case series and review of the literature. Transpl Infect Dis. 2011;13:324-8.

126. Raza K, Ismailjee SB, Crespo M, et al. Successful outcome of human metapneumovirus (hMPV) pneumonia in a lung transplant recipient treated with intravenous ribavirin. J Heart Lung Transplant. 2007;26:862-4.

127. Williams JV, Chen Z, Cseke G, et al. A recombinant human monoclonal antibody to human metapneumovirus fusion protein that neutralizes virus in vitro and is effective therapeutically in vivo. $\mathrm{J}$ Virol. 2007;81:8315-24.

128. Ulbrandt ND, Ji H, Patel NK, et al. Isolation and characterization of monoclonal antibodies which neutralize human metapneumovirus in vitro and in vivo. J Virol. 2006;80:7799-806. 
129. Deffrasnes C, Hamelin ME, Prince GA, Boivin G. Identification and evaluation of a highly effective fusion inhibitor for human metapneumovirus. Antimicrob Agents Chemother. 2008;52:279-87.

130. Kanne JP, Godwin JD, Franquet T, Escuissato DL, Muller NL. Viral pneumonia after hematopoietic stem cell transplantation: high-resolution CT findings. J Thorac Imaging. 2007;22:292-9.

131. Ko JP, Shepard JA, Sproule MW, et al. CT manifestations of respiratory syncytial virus infection in lung transplant recipients. J Comput Assist Tomogr. 2000;24:235-41.

132. Ferguson PE, Sorrell TC, Bradstock KF, Carr P, Gilroy NM. Parainfluenza virus type 3 Pneumonia in bone marrow transplant recipients: multiple small nodules in high-resolution lung computed tomography scans provide a radiological clue to diagnosis. Clin Infect Dis. 2009;48(7):905-9.

133. Franquet T, Rodriguez S, Martino R, Salinas T, Gimenez A, Hidalgo A. Human metapneumovirus infection in hematopoietic stem cell transplant recipients: high-resolution computed tomography findings. J Comput Assist Tomogr. 2005;29:223-7.

134. Franquet T, Rodriguez S, Martino R, Gimenez A, Salinas T, Hidalgo A. Thin-section CT findings in hematopoietic stem cell transplantation recipients with respiratory virus pneumonia. AJR Am J Roentgenol. 2006;187:1085-90.

135. Escuissato DL, Gasparetto EL, Marchiori E, et al. Pulmonary infections after bone marrow transplantation: high-resolution CT findings in 111 patients. AJR Am J Roentgenol. 2005;185:608-15.

136. Gasparetto EL, Escuissato DL, Marchiori E, Ono S, Frare e Silva RL, Muller NL. High-resolution CT findings of respiratory syncytial virus pneumonia after bone marrow transplantation. AJR Am J Roentgenol. 2004;182:1133-7.

137. Kamboj M, Gerbin M, Huang CK, et al. Clinical characterization of human metapneumovirus infection among patients with cancer. J Infect. 2008;57:464-71.

138. Miller WT Jr, Barbosa E Jr, Mickus TJ, Mullin C, Van Deerlin VM, Shiley KT. Chest computed tomographic imaging characteristics of viral acute lower respiratory tract illnesses: a case-control study. J Comput Assist Tomogr. 2011;35:524-30.

139. Shiley KT, Van Deerlin VM, Miller WT Jr. Chest CT features of community-acquired respiratory viral infections in adult inpatients with lower respiratory tract infections. J Thorac Imaging. 2010;25:68-75.

140. Mahony JB. Detection of respiratory viruses by molecular methods. Clin Microbiol Rev. 2008;21:716-47.

141. Fan J, Henrickson KJ. Rapid diagnosis of human parainfluenza virus type 1 infection by quantitative reverse transcription-PCRenzyme hybridization assay. J Clin Microbiol. 1996;34:1914-7.

142. Fan J, Henrickson KJ, Savatski LL. Rapid simultaneous diagnosis of infections with respiratory syncytial viruses A and B, influenza viruses $A$ and $B$, and human parainfluenza virus types 1,2 , and 3 by multiplex quantitative reverse transcription-polymerase chain reaction-enzyme hybridization assay (Hexaplex). Clin Infect Dis. 1998;26:1397-402.

143. Kuypers J, Campbell AP, Cent A, Corey L, Boeckh M. Comparison of conventional and molecular detection of respiratory viruses in hematopoietic cell transplant recipients. Transpl Infect Dis. 2009;11:298-303.

144. Mahony JB, Petrich A, Smieja M. Molecular diagnosis of respiratory virus infections. Crit Rev Clin Lab Sci. 2011;48:217-49.

145. Hammond SP, Gagne LS, Stock SR, et al. Respiratory virus detection in immunocompromised patients with FilmArray respiratory panel compared to conventional methods. J Clin Microbiol. 2012;50:3216-21.

146. Poritz MA, Blaschke AJ, Byington CL, et al. FilmArray, an automated nested multiplex PCR system for multi-pathogen detection: development and application to respiratory tract infection. PLoS One. 2011;6:e26047.
147. Tomblyn M, Chiller T, Einsele H, et al. Guidelines for preventing infectious complications among hematopoietic cell transplant recipients: a global perspective. Preface. Bone Marrow Transplant. 2009;44:453-5.

148. Hall CB, Douglas RG Jr, Schnabel KC, Geiman JM. Infectivity of respiratory syncytial virus by various routes of inoculation. Infect Immun. 1981;33:779-83.

149. Jalal H, Bibby DF, Bennett J, et al. Molecular investigations of an outbreak of parainfluenza virus type 3 and respiratory syncytial virus infections in a hematology unit. J Clin Microbiol. 2007;45:1690-6.

150. Kassis C, Champlin RE, Hachem RY, et al. Detection and control of a nosocomial respiratory syncytial virus outbreak in a stem cell transplantation unit: the role of palivizumab. Biol Blood Marrow Transplant. 2010;16:1265-71.

151. Sydnor ER, Greer A, Budd AP, et al. An outbreak of human parainfluenza virus 3 infection in an outpatient hematopoietic stem cell transplantation clinic. Am J Infect Control. 2012;40(7):601-5.

152. Tu CC, Chen LK, Lee YS, et al. An outbreak of human metapneumovirus infection in hospitalized psychiatric adult patients in Taiwan. Scand J Infect Dis. 2009;41:363-7.

153. Nichols WG, Erdman DD, Han A, Zukerman C, Corey L, Boeckh M. Prolonged outbreak of human parainfluenza virus 3 infection in a stem cell transplant outpatient department: insights from molecular epidemiologic analysis. Biol Blood Marrow Transplant. 2004;10:58-64.

154. Tablan OC, Anderson LJ, Besser R, Bridges C, Hajjeh $\mathrm{R}$. Guidelines for preventing health-care--associated pneumonia, 2003: recommendations of CDC and the Healthcare Infection Control Practices Advisory Committee. MMWR Recomm Rep. 2004:53:1-36.

155. Yokoe D, Casper C, Dubberke E, et al. Infection prevention and control in health-care facilities in which hematopoietic cell transplant recipients are treated. Bone Marrow Transplant. 2009;44:495-507.

156. http://www.cdc.gov/hicpac/pdf/isolation/Isolation2007.pdf. 2007.

157. Cortez K, Murphy BR, Almeida KN, et al. Immune-globulin prophylaxis of respiratory syncytial virus infection in patients undergoing stem-cell transplantation. J Infect Dis. 2002;186:834-8.

158. Le Bayon JC, Lina B, Rosa-Calatrava M, Boivin G. Recent developments with live-attenuated recombinant paramyxovirus vaccines. Rev Med Virol. 2013;23(1):15-34.

159. Graham BS. Vaccine development for respiratory syncytial virus. Curr Opin Virol. 2017;23:107-12.

160. Marquez-Escobar VA. Current developments and prospects on human metapneumovirus vaccines. Expert Rev Vaccines. 2017;16:419-31.

161. Pawelczyk M, Kowalski ML. The role of human Parainfluenza virus infections in the immunopathology of the respiratory tract. Curr Allergy Asthma Rep. 2017;17:16.

162. Peck AJ, Corey L, Boeckh M. Pretransplantation respiratory syncytial virus infection: impact of a strategy to delay transplantation. Clin Infect Dis. 2004;39:673-80.

163. Waghmare A, Englund JA, Boeckh M. How I treat respiratory viral infections in the setting of intensive chemotherapy or hematopoietic cell transplantation. Blood. 2016;127:2682-92.

164. Kumar D, Blumberg EA, Danziger-Isakov L, et al. Influenza vaccination in the organ transplant recipient: review and summary recommendations. Am J Transplant. 2011;11:2020-30.

165. Ng BJ, Glanville AR, Snell G, et al. The impact of pandemic influenza A H1N1 2009 on Australian lung transplant recipients. Am J Transplant. 2011;11:568-74.

166. Vilchez RA, McCurry K, Dauber J, et al. Influenza virus infection in adult solid organ transplant recipients. Am J Transplant. 2002:2:287-91. 
167. Choi SM, Boudreault AA, Xie H, Englund JA, Corey L, Boeckh M. Differences in clinical outcomes after 2009 influenza A/H1N1 and seasonal influenza among hematopoietic cell transplant recipients. Blood. 2011;117:5050-6.

168. Boudreault AA, Xie H, Leisenring W, Englund J, Corey L, Boeckh M. Impact of corticosteroid treatment and antiviral therapy on clinical outcomes in hematopoietic cell transplant patients infected with influenza virus. Biol Blood Marrow Transplant. 2011;17:979-86.

169. Kumar D, Michaels MG, Morris MI, et al. Outcomes from pandemic influenza A H1N1 infection in recipients of solidorgan transplants: a multicentre cohort study. Lancet Infect Dis. 2010;10:521-6.

170. Ljungman P, de la Camara R, Perez-Bercoff L, et al. Outcome of pandemic H1N1 infections in hematopoietic stem cell transplant recipients. Haematologica. 2011;96:1231-5.

171. Elicker BM, Schwartz BS, Liu C, et al. Thoracic CT findings of novel influenza A (H1N1) infection in immunocompromised patients. Emerg Radiol. 2010;17:299-307.

172. Cordero E, Perez-Romero P, Moreno A, et al. Pandemic influenza $\mathrm{A}(\mathrm{H} 1 \mathrm{~N} 1)$ virus infection in solid organ transplant recipients: impact of viral and non-viral co-infection. Clin Microbiol Infect. 2012; 18:67-73.

173. Lee N, Chan PK, Lui GC, et al. Complications and outcomes of pandemic 2009 Influenza A (H1N1) virus infection in hospitalized adults: how do they differ from those in seasonal influenza? J Infect Dis. 2011;203:1739-47.

174. Liu C, Schwartz BS, Vallabhaneni S, et al. Pandemic (H1N1) 2009 infection in patients with hematologic malignancy. Emerg Infect Dis. 2010;16:1910-7.

175. Beutel G, Wiesner O, Eder M, et al. Virus-associated hemophagocytic syndrome as a major contributor to death in patients with 2009 influenza A (H1N1) infection. Crit Care. 2011;15:R80.

176. Vu DL, Bridevaux PO, Aubert JD, Soccal PM, Kaiser L. Respiratory viruses in lung transplant recipients: a critical review and pooled analysis of clinical studies. Am J Transplant. 2011;11:1071-8.

177. Lee N, Chan PK, Hui DS, et al. Viral loads and duration of viral shedding in adult patients hospitalized with influenza. J Infect Dis. 2009;200:492-500.

178. Ng S, Cowling BJ, Fang VJ, et al. Effects of oseltamivir treatment on duration of clinical illness and viral shedding and household transmission of influenza virus. Clin Infect Dis. 2010;50:707-14.

179. Khanna N, Steffen I, Studt JD, et al. Outcome of influenza infections in outpatients after allogeneic hematopoietic stem cell transplantation. Transpl Infect Dis. 2009;11:100-5.

180. Harper SA, Bradley JS, Englund JA, et al. Seasonal influenza in adults and children--diagnosis, treatment, chemoprophylaxis, and institutional outbreak management: clinical practice guidelines of the Infectious Diseases Society of America. Clin Infect Dis. 2009;48:1003-32.

181. Moscona A. Global transmission of oseltamivir-resistant influenza. N Engl J Med. 2009;360:953-6.

182. Hurt AC, Lee RT, Leang SK, et al. Increased detection in Australia and Singapore of a novel influenza A(H1N1)2009 variant with reduced oseltamivir and zanamivir sensitivity due to a $\mathrm{S} 247 \mathrm{~N}$ neuraminidase mutation. Euro surveillance: bulletin europeen sur les maladies transmissibles = European communicable disease bulletin 2011;16.

183. Centers for Disease Control. Flu. www.cdc.gov/flu. Accessed Sept 2018.

184. Ison MG, Gubareva LV, Atmar RL, Treanor J, Hayden FG. Recovery of drug-resistant influenza virus from immunocompromised patients: a case series. J Infect Dis. 2006;193:760-4.

185. Weinstock DM, Gubareva LV, Zuccotti G. Prolonged shedding of multidrug-resistant influenza $\mathrm{A}$ virus in an immunocompromised patient. N Engl J Med. 2003;348:867-8.
186. Graitcer SB, Gubareva L, Kamimoto L, et al. Characteristics of patients with oseltamivir-resistant pandemic (H1N1) 2009, United States. Emerg Infect Dis. 2011;17:255-7.

187. McGeer A, Green KA, Plevneshi A, et al. Antiviral therapy and outcomes of influenza requiring hospitalization in Ontario, Canada. Clin Infect Dis. 2007;45:1568-75.

188. Machado CM. Influenza infections after hematopoietic stem cell transplantation. Clin Infect Dis. 2005;41:273-4.

189. Casper C, Englund J, Boeckh M. How I treat influenza in patients with hematologic malignancies. Blood. 2010;115:1331-42.

190. Ison MG, Michaels MG. RNA respiratory viral infections in solid organ transplant recipients. Am J Transplant. 2009;9(Suppl 4):S166-72.

191. Kumar D, Morris MI, Kotton CN, et al. Guidance on novel influenza A/H1N1 in solid organ transplant recipients. Am J Transplant. 2010;10:18-25.

192. Nicholson KG, Aoki FY, Osterhaus AD, et al. Efficacy and safety of oseltamivir in treatment of acute influenza: a randomised controlled trial. Neuraminidase Inhibitor Flu Treatment Investigator Group. Lancet. 2000;355:1845-50.

193. Treanor JJ, Hayden FG, Vrooman PS, et al. Efficacy and safety of the oral neuraminidase inhibitor oseltamivir in treating acute influenza: a randomized controlled trial. US Oral Neuraminidase Study Group. JAMA. 2000;283:1016-24.

194. Ison MG. Influenza prevention and treatment in transplant recipients and immunocompromised hosts. Influenza Other Respir Viruses. 2013;7(Suppl 3):60-6.

195. Beigel JH, Bao Y, Beeler J, et al. Oseltamivir, amantadine, and ribavirin combination antiviral therapy versus oseltamivir monotherapy for the treatment of influenza: a multicentre, double-blind, randomised phase 2 trial. Lancet Infect Dis. 2017;17:1255-65.

196. Rubin LG, Levin MJ, Ljungman P, et al. 2013 IDSA clinical practice guideline for vaccination of the immunocompromised host. Clin Infect Dis. 2014;58:e44-100.

197. Machado CM, Cardoso MR, da Rocha IF, Boas LS, Dulley FL, Pannuti CS. The benefit of influenza vaccination after bone marrow transplantation. Bone Marrow Transplant. 2005;36:897-900.

198. DiazGranados CA, Dunning AJ, Kimmel M, et al. Efficacy of high-dose versus standard-dose influenza vaccine in older adults. N Engl J Med. 2014;371:635-45.

199. Halasa NB, Savani BN, Asokan I, et al. Randomized double-blind study of the safety and immunogenicity of standard-dose trivalent inactivated influenza vaccine versus high-dose trivalent inactivated influenza vaccine in adult hematopoietic stem cell transplantation patients. Biol Blood Marrow Transplant. 2016;22:528-35.

200. Chong PP, Handler L, Weber DJ. A systematic review of safety and immunogenicity of influenza vaccination strategies in solid organ transplant recipients. Clin Infect Dis. 2018;66:1802-11.

201. Natori Y, Shiotsuka M, Slomovic J, et al. A double-blind, randomized trial of high-dose vs standard-dose influenza vaccine in adult solid-organ transplant recipients. Clin Infect Dis. 2018;66:1698-704.

202. Thomas RE, Jefferson T, Lasserson TJ. Influenza vaccination for healthcare workers who work with the elderly. Cochrane Database Syst Rev. 2010:CD005187.

203. Zaki AM, van Boheemen S, Bestebroer TM, Osterhaus AD, Fouchier RA. Isolation of a Novel Coronavirus from a man with Pneumonia in Saudi Arabia. N Engl J Med. 2012;367(19): 1814-20.

204. de Wit E, van Doremalen N, Falzarano D, Munster VJ. SARS and MERS: recent insights into emerging coronaviruses. Nat Rev Microbiol. 2016;14:523-34.

205. Uhlenhaut C, Cohen JI, Pavletic S, et al. Use of a novel virus detection assay to identify coronavirus HKU1 in the lungs of a hematopoietic stem cell transplant recipient with fatal pneumonia. Transpl Infect Dis. 2012;14:79-85. 
206. Oosterhof L, Christensen CB, Sengelov H. Fatal lower respiratory tract disease with human corona virus NL63 in an adult haematopoietic cell transplant recipient. Bone Marrow Transplant. 2010;45:1115-6.

207. Gutman JA, Peck AJ, Kuypers J, Boeckh M. Rhinovirus as a cause of fatal lower respiratory tract infection in adult stem cell transplantation patients: a report of two cases. Bone Marrow Transplant. 2007;40:809-11.

208. Ogimi C, Waghmare AA, Kuypers JM, et al. Clinical significance of human coronavirus in bronchoalveolar lavage samples from hematopoietic cell transplant recipients and patients with hematologic malignancies. Clin Infect Dis. 2017;64:1532-9. 